Tersedia online di: http://ejournal-balitbang.kkp.go.id/index.php/bawal
e-mail:bawal.puslitbangkan@ @mail.com
BAWAL wIDYA RISET PERIKANAN TANGKAP
Volume 9 Nomor 1 April 2017
p-ISSN: 1907-8226
e-ISSN: 2502-6410
BAWAL
Nomor Akreditasi: $620 /$ AU2/P2MI-LIPI/03/2015
BAWAL

\title{
BEBERAPA ASPEK BIOLOGI UDANG BANANA (Metapenaeus dobsoni) DAN UDANG KAYU (M. affinis) DI PERAIRAN TELUK CEMPI, NUSA TENGGARA BARAT
}

\section{SOME BIOLOGICAL ASPECTS OF Metapenaeus dobsoni AND M. affinis IN THE CEMPI BAY WATERS, WEST NUSA TENGGARA}

\author{
Masayu Rahmia Anwar Putri*1dan Adriani Sri Nastiti ${ }^{1}$ \\ ${ }^{1}$ Balai Penelitian Pemulihan dan Konservasi Sumberdaya Ikan, Jl. Cilalawi No. 1, Jatiluhur, Purwakarta \\ Teregistrasi I tanggal: 28 Juni 2016; Diterima setelah perbaikan tanggal: 03 Maret 2017; \\ Disetujui terbit tanggal: 06 Maret 2017
}

\begin{abstract}
ABSTRAK
Perairan Teluk Cempi merupakan salah satu daerah penangkapan udang potensial di Nusa Tenggara Barat khususnya udang benana (Metapenaeus dobsoni) dan udang kayu (M. affinis). Pemanfaatan sumberdaya udang yang tidak terkendali akan mengancam kelestarian sumberdaya udang. Sebagai dasar untuk pengelolaan yang berkelanjutan perlu dilakukan kajian beberapa parameter biologi meliputi nisbah kelamin, sebaran ukuran panjang, hubungan panjang dan berat, tingkat kematangan gonad, ukuran pertama kali matang gonad dan ukuran pertama kali tertangkap. Penelitian ini dilaksanakan di perairan Teluk Cempi, Nusa Tenggara Barat pada bulan AprilDesember 2013. Sampel udang didapatkan dari percobaan penangkapan dan hasil tangkapan nelayan yang didaratkan di Desa Jala, Kabupaten Dompu, kemudian dicatat data biologinya oleh enumerator. Hasil penelitian menunjukkan nisbah kelamin udang kayu dan banana betina lebih banyak dibandingkan udang jantan (lebih dari $60 \%$ ). Panjang karapas udang benana dan udang kayu betina lebih besar dibandingkan udang jantan. Pola pertumbuhan udang benana dan udang kayu alometrik negatif. Udang benana dan udang kayu di Teluk Cempi dapat memijah sepanjang tahun. Hasil tangkapan udang didominasi udang yang belum matang gonad (TKG I-II). Udang benana pertama kali matang gonad (Lm) pada ukuran $24 \mathrm{~mm}$ dan Lm udang kayu pada ukuran 26,2 mm. Ukuran udang benana pertama kali tertangkap (Lc) adalah 16,25 $\mathrm{mm}$ (jantan) dan 19,69 $\mathrm{mm}$ (betina), sedangkan Lc udang kayu diperoleh $19 \mathrm{~mm}$ (jantan) dan 24,57 mm (betina). Tekanan penangkapan udang di Teluk Cempi sudah sangat intesif yang terindikasi dari tingginya hasil tangkapan udang yang belum matang gonad dan nilai Lc yang lebih kecil dari Lm.
\end{abstract}

Kata Kunci: Aspek biologi; Metapenaeus dobsoni; M. affinis; Teluk Cempi

\section{ABSTRACT}

The Cempi Bay is one of the potential fishing ground of shrimp in West Nusa Tenggara, especially for Metapenaeus dobsoni and M.affinis. The unmanaged exploitation leads to unsustainability of shrimp resources. As a basis for sustainable management it is necessary to study several biological parameters such as sex ratio, length distribution, length and weight relationship, maturity stages, the length at first maturity and length at first capture. This research was conducted in Cempi Bay Waters on April to December 2013. Samples were obtained from experimental fishing and fisherman's catch that landed in Jala Village, Dompu Regency, then its biology data recorded by enumerators. The results showed that sex ratio offemales Metapenaeus affinis and M. dobsoni was higher than males (more than 60\%). The carapace length of M.dobsoni and M. affinis was larger than males. The growth pattern of both M.dobsoni and M.affinis were allometric negative. Both shrimp species may spawn throughout the year. The shrimp catch dominated immature stage (I-II maturity stages). The carapace length at first maturity $(\mathrm{Lm})$ of M.dobsoni was $24 \mathrm{~mm}$ and Lm of M.affinis was $26.2 \mathrm{~mm}$. The carapace length at first capture (Lc) of M.dobsoni was $16.25 \mathrm{~mm}$ (male) and $19.69 \mathrm{~mm}$ (female), while the Lc of M.affinis was 19 $\mathrm{mm}$ (male) and $24.57 \mathrm{~mm}$ (female). The pressure of shrimp fishing in Cempi Bay has been very intensive, indicated by the high catches of immature shrimp and the value of Lc was smaller than Lm.

Keywords: Biological aspect; Metapenaeus dobsoni; M. affinis; Cempi Bay

Korespondensi penulis:

e-mail:masayurahmia33@gmail.com

Telp. (0264) 208768/081278088236 


\section{PENDAHULUAN}

Pemanfaatan sumberdaya udang sebagai komoditas penting di Indonesia semakin hari semakin meningkat. Perikanan udang merupakan sumberdaya perikanan ekspor terbesar di Indonesia. Sebanyak 81 spesies udang Penaeid ditemukan di Indonesia dan setidaknya 46 spesies ini telah tertangkap dan hanya 14 diantaranya dikategorikan penting secara ekonomi, termasuk udang dari genus Metapenaeus (Gillet, 2008; Chan, 1998; Suman, 2010). Saat ini produksi udang Indonesia dari genus Metapenaeus lebih besar dari produksi udang dari genus Penaeus, yang merupakan jenis udang untuk tujuan ekspor (Gillet, 2008).

Perairan Teluk Cempi di Kabupaten Dompu merupakan salah satu daerah penangkapan udang potensial. Tahun 2013, perairan laut Kabupaten Dompu menyumbang 59\% produksi udang di Nusa Tenggara Barat, dengan produksi udang sebesar 1.520,9 ton (Badan Perencanaan Pembangunan Daerah dan Badan Pusat Statistik Provinsi NTB, 2014). Sumiono \& Prisantoso (1991) menyatakan jenis udang yang umum ditangkap di perairan ini diantaranya Penaeus merguensis, $P$. indicus, P. monodon, P. semisulcatus, P. latisulcatus, Metapenaeus ensis, M. lysianasa dan Parapenaeopsis sculptilis. Jenis udang Metapenaeus yang ditemukan pada penelitian tersebut berbeda dengan hasil penelitian Nastiti et al. (2012), dimana dua jenis udang dari genus Metapenaeus yang sering tertangkap nelayan di Teluk Cempi adalah Metapenaeus affinis (udang kayu) dan Metapenaeus dobsoni (udang benana).

Pemanfaatan sumberdaya udang yang terus menerus dilakukan tanpa pembatasan akan mengancam kelestarian sumberdayanya di alam, sehingga dibutuhkan data dan informasi pendukung untuk melakukan pengelolaan yang rasional (Nurdin \& Kembaren, 2015). Data dan informasi tentang aspek biologi seperti biologi reproduksi diperlukan dalam pengkajian stok dan pengelolaan populasi ikan (Kjesbu, 2009; Nurdin \& Kembaren, 2015). Terkait dengan terbatasnya data dan informasi biologi udang di Teluk Cempi, perlu dilakukan kajian nisbah kelamin, sebaran panjang dan berat, hubungan panjang dan berat, TKG, ukuran pertama kali matang gonad dan pertama kali tertangkap dari udang benana (Metapenaeus dobsoni) dan udang kayu (M.affinis).

\section{BAHANDANMETODE}

Penelitian ini dilaksanakan di perairan Teluk Cempi, Nusa Tenggara Barat (Gambar 1) pada bulan AprilDesember 2013. Sampel udang didapatkan dari percobaan penangkapan dan hasil tangkapan nelayan yang didaratkan di Desa Jala, Kecamatan Hu'u, Kabupaten Dompu. Udang ditangkap dengan menggunakan trammel net dengan ukuran mata jaring bagian luar 5 inci, mata jaring bagian dalam 1,15 inci untuk udang benana dan 1,25 inci untuk udang kayu. Data biologi udang (panjang karapas, berat, jenis kelamin dan tingkat kematangan gonad) dilakukan oleh enumerator yang telah dilatih tentang pengenalan jenis dan metode sampling biologi udang. Panjang karapas udang ( $\mathrm{mm}$ ) diukur menggunakan jangka sorong (tingkat ketelitian 0,05 $\mathrm{mm}$ ) dan beratnya diukur menggunakan timbangan digital $(0,01 \mathrm{~g})$. Data panjang karapas dan berat udang kemudian ditabulasikan dalam program Microsoft Excel.

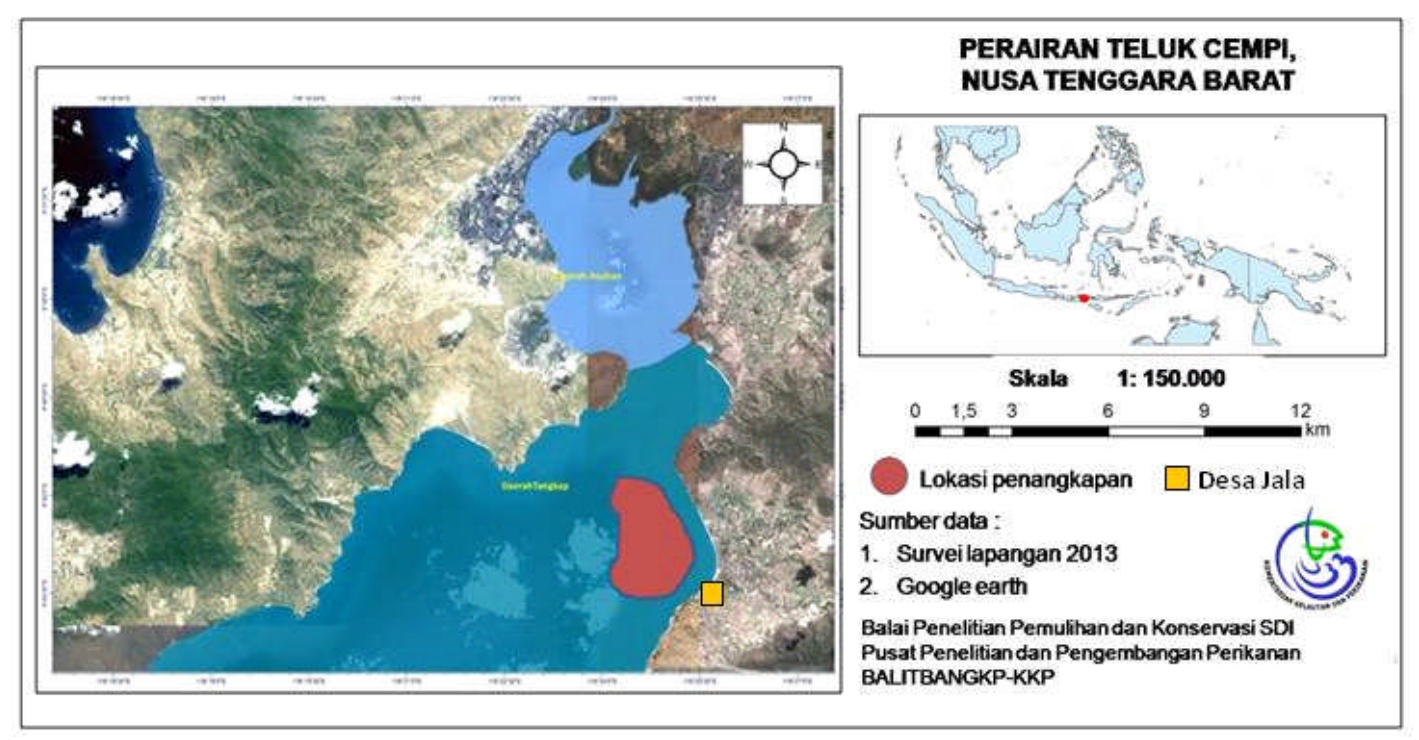

Gambar 1. Peta Lokasi Penelitian.

Figure 1. Research Location map. 
Udang yang tertangkap diidentifikasi mengacu pada Chan (1998) dan dipisahkan antara jantan dan betina dengan membedakan organ reproduksi eksternalnya (Thelycum, organ reproduksi udang betina dan Petasma, organ reproduksi udang jantan). Tingkat kematangan gonad (TKG) udang betina (I-V) ditentukan berdasarkan kriteria makroskopik. Kriteria tingkat kematangan gonad udang dikemukakan oleh Naamin (1984) yaitu: (1) dara (undeveloped) dan (2) berkembang (developed) dicirikan dengan ovari terlihat bening (translucent), (3) hampir

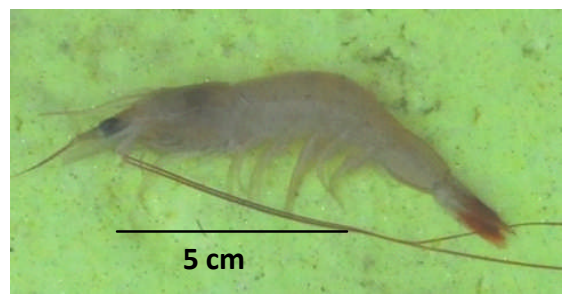

Udang benana (Metapenaeus dobsoni) matang (early mature), warna ovari berubah dari pucat menjadi kuning, (4) matang (ripe), warna ovary menjadi hijau gelap dan (5) salin (spent), ovari berwarna hijau keabu-abuan. Udang diklasifikasikan sebagai udang belum matang gonad (immature) pada TKG I-II dan diklasifikasikan sebagai udang yang matang gonad (mature) pada TKG III-IV (Nalini, 1976). Jenis udang yang dikaji dalam tulisan ini adalah udang benana (Metapenaeus dobsoni) dan udang kayu (Metapenaeus affinis), disajikan pada Gambar 2.

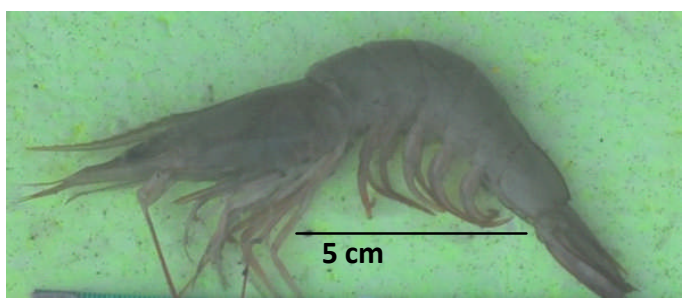

Udang kayu (Metapenaeus affinis)

Gambar 2. Dua jenis udang Metapenaeus yang sering tertangkap di Teluk Cempi.

Figure 2. Two species of Metapenaeus that often captured in Cempi Gulf.

\section{Analisis Data}

Nisbah kelamin udang diketahui berdasarkan perbandingan jumlah udang jantan dan betina yang tertangkap selama penelitian (Effendi, 1997).

Hubungan panjang karapas dan berat kedua jenis udang diketahui menggunakan metode Effendie (1997):

$$
\mathbf{W}=\mathbf{a L}^{\mathbf{b}}
$$

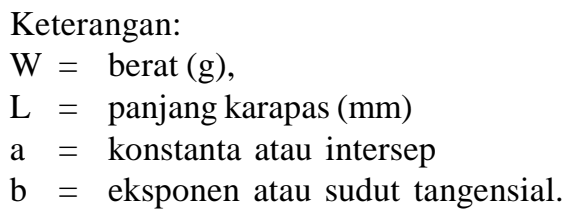

Keterangan:

$\mathrm{W}=$ berat $(\mathrm{g})$,

$\mathrm{L}=$ panjang karapas $(\mathrm{mm})$

$\mathrm{a}=$ konstanta atau intersep

$\mathrm{b}=$ eksponen atau sudut tangensial.

Persamaan tersebut dapat digambarkan dalam bentuk linier dengan membuat logaritma sehingga menjadi $\log \mathrm{W}$ $=\log a+b \log L$. Jika $b$ sama dengan $3(b=3)$ maka pertumbuhan bersifat isometrik dan jika $b$ tidak sama dengan 3 (b 3) maka pertumbuhan bersifat alometrik (b > 3 adalah alometrik positif dan $b<3$ adalah alometrik negatif). Untuk mengetahui sifat pertumbuhannya, dilakukan uji t pada nilai $b$. Apabila $t_{\text {hitung }}>t_{\text {table }}$ maka hipotesis nol diterima (nilai b tidak berbeda nyata dengan 3) (Triharyuni et al., 2012).

Penentuan panjang karapas rata-rata udang pertama kali tertangkap $\left(\mathrm{cL}_{50 \%}\right)$ dilakukan dengan menggunakan metode kurva logistik baku, yaitu dengan memplotkan persentase frekuensi kumulatif dengan panjang karapasnya (Triharyuni et al., 2012).
Panjang karapas udang pertama kali matang gonad (cLm) diketahui dengan menggunakan rumus Spearman Karber (Udupa, 1986):

$\mathbf{m}=\mathbf{X k}+(\mathbf{X} / \mathbf{2})-(\mathbf{X S P i})$

dimana:

$\mathrm{m}=$ log panjang udang pada kematangan gonad pertama

$\mathrm{Xk}=\log$ nilai tengah kelas panjang dimana semua udang (100\%) sudah matang gonad

$\mathrm{p}_{\mathrm{i}}=$ proporsi udang matang pada kelas ke I dimana $\mathrm{pi}=$ ri/ni apabila $\mathrm{ni}=\mathrm{ni}+1$

ri $=$ jumlah udang matang pada kelas panjang ke $\mathrm{i}$

Panjang udang pada waktu mencapai kematangan yang pertama (M) diketahui dengan menggunakan rumus:

$M=m \pm 1,96 \sqrt{ } X^{2}\left(p_{i}^{*} * q_{i}\right) / n i-1$

Panjang total dari udang jantan dan betina dari udang benana dan udang kayu hasil tangkapan di Teluk Cempi didapatkan dengan menggunakan persamaan dari Ramamurthy \& Manickaraja (1978) (Lampiran 1).

\section{HASIL DAN BAHASAN Hasil}

\section{Nisbah Kelamin}

Selama penelitian didapatkan sebanyak 5.347 ekor udang Metapenaeus spp.yang terdiri dari 3.349 ekor udang benana (Metapeneaus dobsoni) dan 1.999 ekor udang kayu (M. affinis). Komposisi dan nisbah kelamin kedua 
jenis ikan tersebut ditampilkan pada Tabel 1. Setiap bulannya nisbah kelamin udang betina dari kedua jenis udang lebih banyak dibandingkan udang jantan (lebih dari $60 \%$ ), dimana perbandingan udang benana betina berkisar antara 61,26-86,84\%, dan pada udang kayu betina berkisar antara 59,2-78,44\%.Rata-rata nisbah kelamin (NK) udang benana dan udang kayu masing-masing sebesar 1:3,75 dan 1:2,39 dan berfluktuasi setiap bulannya.

Tabel 1. Komposisi dan nisbah kelamin udang benana dan udang kayu

Table 1. Sex composition and ratio of M. dobsoni and M. affinis

\begin{tabular}{|c|c|c|c|c|c|c|}
\hline \multirow{3}{*}{ Bulan/Month } & \multicolumn{3}{|c|}{ Udang Benana/ M. dobsoni } & \multicolumn{3}{|c|}{ Udang kayu/M. affinis } \\
\hline & \multicolumn{2}{|c|}{$\begin{array}{l}\text { Komposisi (\%)/ } \\
\text { composition (\%) }\end{array}$} & \multirow{2}{*}{ NK/SR } & \multicolumn{2}{|c|}{$\begin{array}{l}\text { Komposisi (\%)/ } \\
\text { composition (\%) }\end{array}$} & \multirow{2}{*}{ NK/SR } \\
\hline & $\begin{array}{l}\text { Betina/ } \\
\text { Female }\end{array}$ & $\begin{array}{c}\text { Jantan/ } \\
\text { Male }\end{array}$ & & $\begin{array}{l}\text { Betina/ } \\
\text { Female }\end{array}$ & $\begin{array}{c}\text { Jantan/ } \\
\text { Male }\end{array}$ & \\
\hline April & 82,51 & 17,49 & $1: 4,72$ & 65,21 & 34,79 & $1: 1,87$ \\
\hline Mei & 86,84 & 13,16 & $1: 6,6$ & 78,44 & 21,56 & $1: 3,64$ \\
\hline Juni & 80,26 & 19,74 & $1: 4,07$ & 76,02 & 23,98 & $1: 3,17$ \\
\hline Juli & 81,82 & 18,18 & $1: 4,5$ & 66,46 & 33,54 & $1: 1,98$ \\
\hline Agustus & 81,42 & 18,58 & $1: 4,38$ & 61,45 & 38,55 & $1: 1,59$ \\
\hline September & 75,58 & 24,42 & $1: 3,1$ & 76,60 & 23,40 & $1: 3,27$ \\
\hline Oktober & 61,26 & 38,74 & $1: 1,58$ & 67,33 & 32,67 & $1: 2,06$ \\
\hline November & 68,28 & 31,72 & $1: 2,15$ & 59,20 & 40,80 & $1: 1,45$ \\
\hline Desember & 72,92 & 27,08 & $1: 2,69$ & 71,05 & 28,95 & $1: 2,45$ \\
\hline
\end{tabular}

Ket. : NK/SR $=$ Nisbah kelamin/Sex ratio

\section{Distribusi Ukuran dan Hubungan Panjang Karapas Berat}

Ukuran panjang karapas udang benana berkisar antara 11-31,14 mm (rata-rata PK 17,47 mm) dan PK udang kayu berkisar antara 10,16-37,14 mm (rata-rata PK 22,9 $\mathrm{mm}$ ).Distribusi ukuran panjang karapas dari udang benana dan udang kayu ditampilkan pada Gambar 3 dan 4. Panjang karapas udang benana dan udang kayu betina lebih besar dibandingkan yang jantan. Modus panjang karapas udang benana betina pada kelas antara $18-19 \mathrm{~mm}(34,96 \%)$ dan udang benana jantan pada kelas antara 14-15 mm $(34,72 \%)$, sedangkan udang kayu betina didominasi ukuran panjang karapas antara 23-24 mm (16,88\%)dan udang kayu jantan didominasi kelas panjang 21-22 mm $(25,7 \%)$.

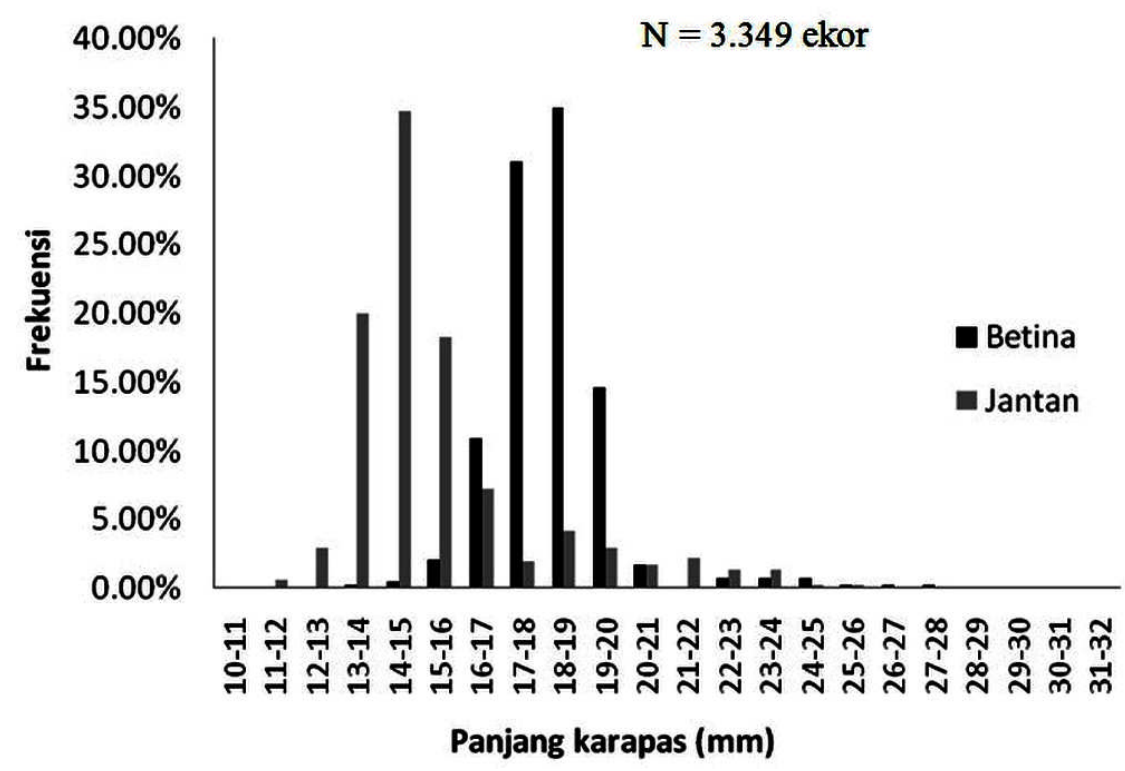

Gambar 3. Distribusi panjang karapas udang banana.

Figure 3. Carapace length distribution of M. dobsoni. 


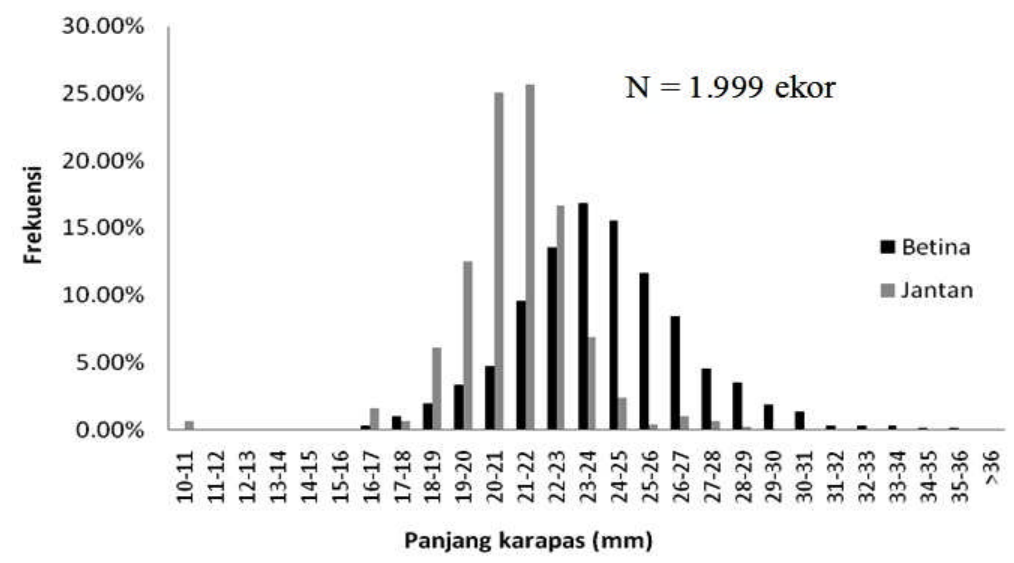

Gambar4. Distribusi panjang karapas udang kayu.

Figure 4. Carapace length distribution of M. affinis.

Hubungan panjang karapas dan berat udang benana dan kayu di perairan Teluk Cempi ditampilkan pada Gambar 5 dan 6. Hasil analisis hubungan panjang karapas berat udang benana jantan dan betina masing-masing diperoleh persamaan $\mathrm{W}=0,008 \mathrm{~L}^{2.122} \mathrm{dan} \mathrm{W}=0,008 \mathrm{~L}^{2,091}$. Persamaan hubungan panjang berat udang kayu betina $\mathrm{W}=0,006 \mathrm{~L}^{2,224} \mathrm{dan}$ jantan $\mathrm{W}=0,018 \mathrm{~L}^{1,909}$. Pola pertumbuhan kedua jenis udang (jantan dan betina) ditunjukkan dengan nilai $\mathrm{t}_{\text {hitung }}<\mathrm{t}_{\text {tabel }}(\mathrm{b}$ ““3), yang artinya pertumbuhan panjang udang lebih cepat dari pertumbuhan beratnya (alometrik negatif).

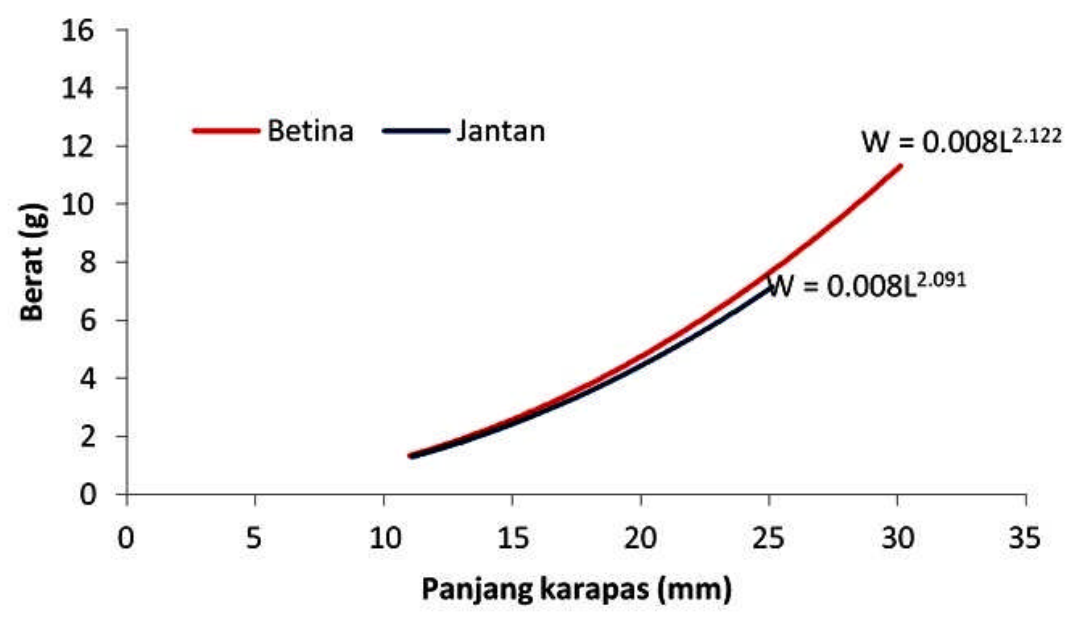

Gambar 5. Hubungan panjang karapas dan berat udang benana.

Figure 5. Carapace length and weight relationship of M. dobsoni.

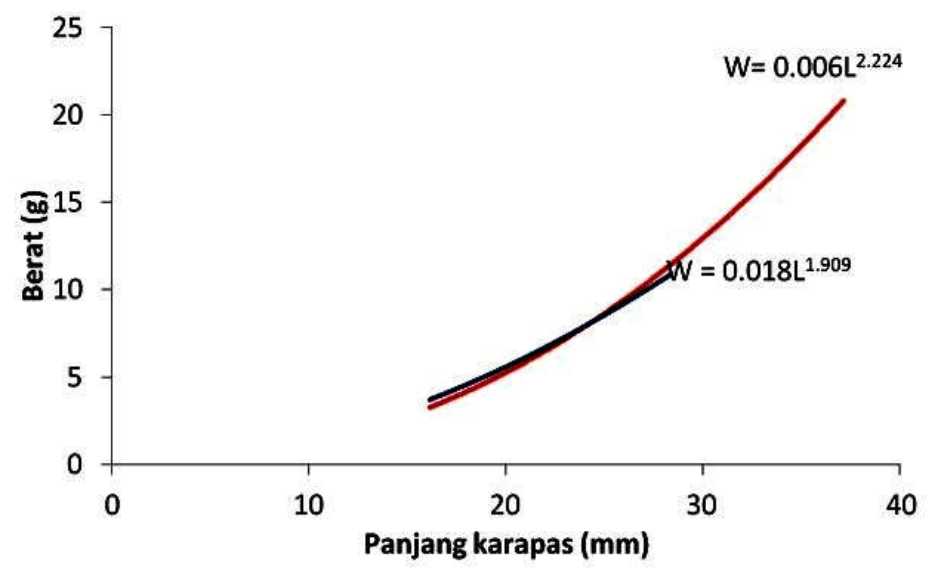

Gambar6. Hubungan panjang karapas dan berat udang kayu.

Figure 6. Carapace length and weight relationship of M. affinis. 
Tingkat Kematangan Gonad, Ukuran Pertama Kali Tertangkap dan Pertama Kali Matang Gonad

Gambar 7 dan 8 menyajikan pola sebaran tingkat kematangan gonad (TKG) udang benana dan udang kayu, udang TKG I-II mendominasi hasil tangkapan (rata-rata lebih dari 50\%). Udang benana yang matang gonad (TKG
III-IV) lebih banyak tertangkap sekitar bulan SeptemberDesember, dengan puncak penangkapannya pada bulan Desember, sementara udang kayu yang matang gonad lebih banyak tertangkap sekitar bulan April-Juli, dengan puncaknya terjadi pada bulan Mei (Gambar9). Diduga puncak musim pemijahan udang benana terjadi pada bulan Desember sedangkan untuk udang kayu terjadi pada bulan Mei.

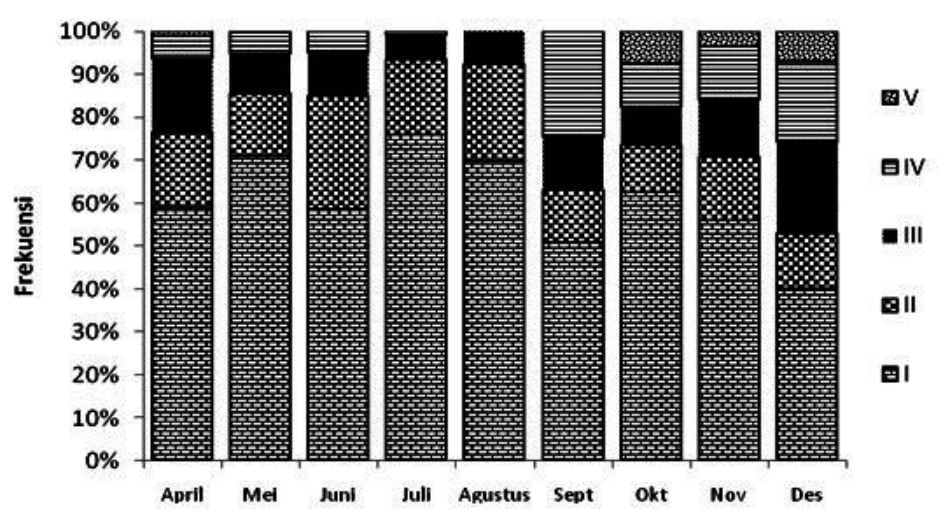

Gambar 7. Sebaran bulanan tingkat kematangan gonad udang banana,M. dobsoni. Gambar 7. Monthly distribution of gonad maturity stage of M. dobsoni.

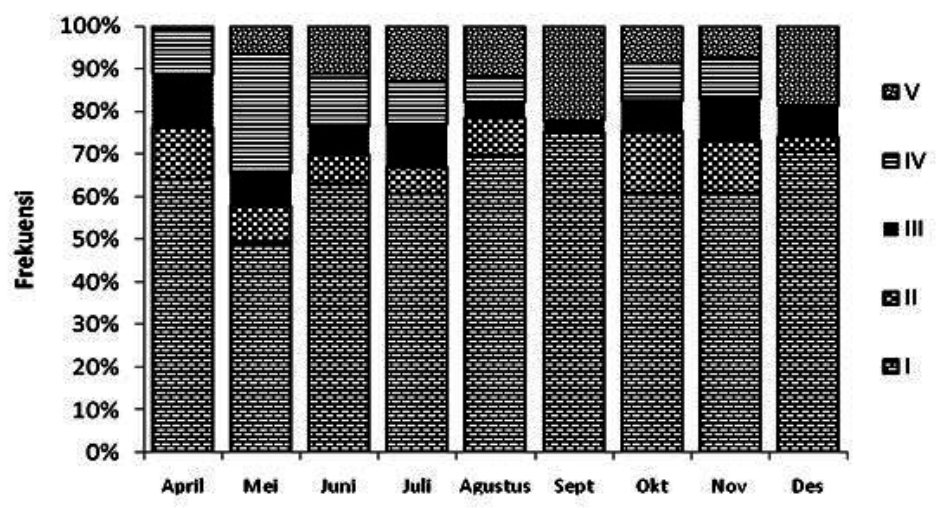

Gambar 8. Sebaran bulanan tingkat kematangan gonad udang kayu,M. affinis. Gambar 8. Monthly distribution of gonad maturity stage of M. affinis.

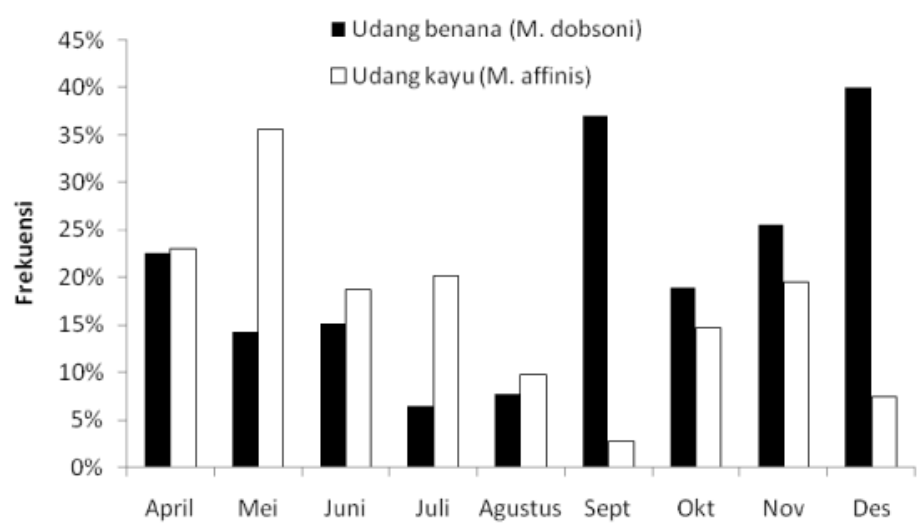

Gambar 9. Persentase TKG III \& IV (matang gonad) M. dobsoni dan M. affinis.

Figure 9. The percentage of III \& IV maturity stage (matured stage) of M. dobsoni and M. affinis.

Ukuran rata-rata udang benana (M. dobsoni) pertama kali tertangkap $\left(\mathrm{L}_{\mathrm{c}}\right)$ diestimasi sebesar $16,25 \mathrm{~mm}$ (jantan) dan 19,69 mm (betina), sedangkan $\mathrm{L}_{\mathrm{c}}$ udang kayu $(M$. affinis) jantan diperoleh19 mm dan udang kayu betina 24,57 mm (Gambar 10 dan 11). 

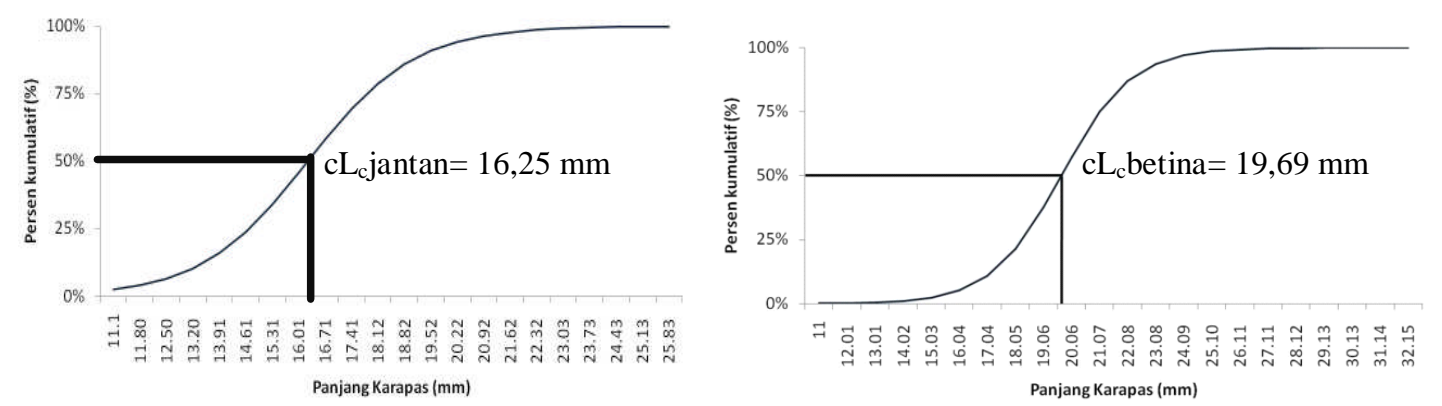

Gambar 10. Ukuran pertama kali tertangkap $\left(\mathrm{L}_{\mathrm{c}}\right)$ udang banana.

Figure 10. Length at first capture $\left(L_{c}\right)$ of $M$. dobsoni.
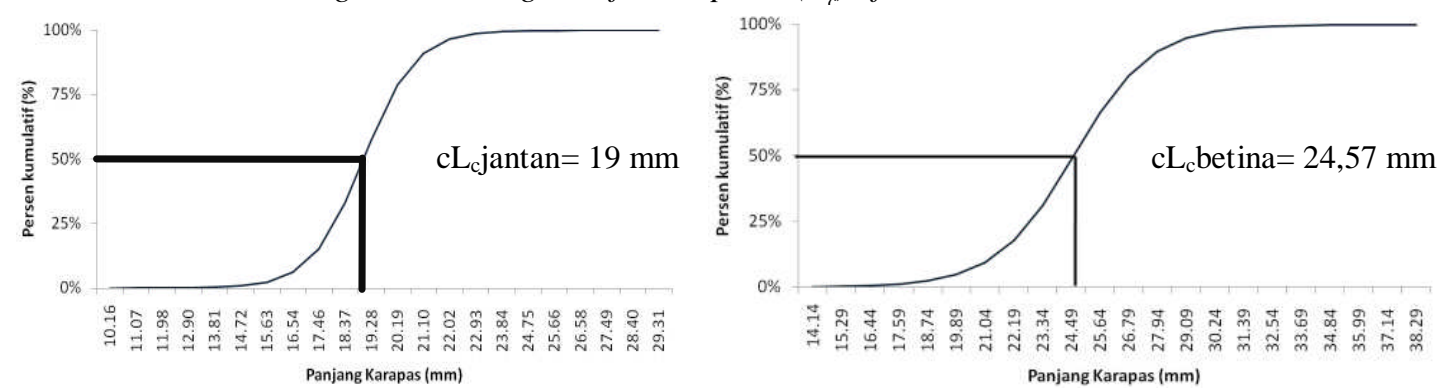

Gambar 11. Ukuran pertama kali tertangkap $\left(\mathrm{L}_{\mathrm{c}}\right)$ udang kayu.

Figure 11. Length at first capture $\left(L_{c}\right)$ of $M$. affinis.

Udang benana pertama kali matang gonad $\left(\mathrm{L}_{\mathrm{m}}\right)$ pada ukuran $24 \mathrm{~mm}$, dengan kisaran antara 23,8-24,2 $\mathrm{mm}$ dan $\mathrm{L}_{\mathrm{m}}$ udang kayu berkisar antara 26-26,4 mm dengan ratarata $L_{m}$ pada ukuran $26,2 \mathrm{~mm}$.

\section{Bahasan}

Selama penelitian berlangsung, udang betina lebih banyak tertangkap dibandingkan udang jantan. Kondisi ini serupa dengan beberapa hasil penelitian lainnya (Saputra et al., 2005; Gerami et al., 2013). Menurut da Costa et al. (2010), jumlah betina yang lebih besar tertangkap berhubungan dengan tingginya kerentanan mereka terhadap aktivitas penangkapan karena ukurannya yang lebih besar dibandingkan udang jantan.

Ukuran udang jantan yang telah diidentifikasi lebih kecil dibandingkan udang betina. Menurut King(2012), udang Penaeid betina lebih besar dibandingkan udang jantan. Naamin (1984) dalam Suman et al. (2007) menyatakan bahwa pertumbuhan udang betina lebih cepat jika dibandingkan dengan udang jantan, sehingga karapas dari udang betina selalu lebih panjang dibandingkan jantan pada umur yang sama. Panjang total (PT) kedua jenis udang saat penelitian diketahui lebih kecil jika dibandingkan PT maksimum udang yang ditemukan di perairan pasifik barat. PT udang benana betina dan jantan di perairan pasifik barat masing-masing 13 dan $11,8 \mathrm{~cm}$, sedangkan untuk udang kayu masing masing memiliki PT sebesar 18,6 cm (betina) dan 14,6 cm (jantan) (Chan, 1998). Kisaran panjang total udang benana betina dan jantan di Teluk Cempi masing-masing 5,4-12,1 cm dan 4,9-10,7 cm, sedangkan untuk udang kayu betina berkisar antara 6,5$14,2 \mathrm{~cm}$ dan untuk udang kayu jantan berkisar antara 4,6$11,7 \mathrm{~cm}$. Peningkatan tekanan penangkapan dan penurunan ukuran rata-rata udang yang tertangkap akan menyebabkan penurunan stok udang (Matthews, 1982). Banyaknya udang ukuran dewasa dan matang gonad yang tertangkap memiliki konsekuensi yang merugikan pada proses rekruitmen (Ogbonna, 2001).

Analisis hubungan panjang karapas dan berat udang benana dan udang kayu menunjukkan pola pertumbuhan alometrik negatif yang sesuai dengan populasi udang benana dan udang kayu yang ditemukan di perairan Cilacap (Saputra et al., 2013), udang dogol (M. affinis) di perairan Kubu Raya (Hedianto \& Riswanto, 2014) tetapi berbeda dengan hasil penelitian $M$. dobsoni dan M. affinis di Goa, India yang menunjukkan pertumbuhan isometrik (Achuthankutty \& Parulekar, 1986). Perbedaan hubungan panjang dan berat dipengaruhi banyak faktor diantaranya kematangan, suhu, salinitas, ketersediaan makanan dan ukuran (Weatherly \& Gill, 1987 dalam Hashemi et al, 2012).

Udang benana dan udang kayu di Teluk Cempi dapat memijah sepanjang tahun sebagaimana hasil penelitian lainnya (Pillai \& Thirumilu, 2013 dan Gerami et al., 2013), dimana puncaknya terjadi pada waktu yang berlainan. Puncak musim pemijahan udang benana yang terjadi antara bulan September- Desember tidak jauh berbeda dengan hasil penelitian Pillai \& Thirumilu (2013) di India yang mana puncak pemijahan udang benana terjadi dua kali, salah satunya antara Desember-Februari. Puncak musim pemijahan udang kayu di Teluk Cempi yang terjadi 
antara April-Juli juga tidak jauh berbeda dengan penelitian Gerami et al. (2013) di Iran yang terjadi pada Maret dan April.

Panjang karapas saat pertama kali matang gonad (Lm) dari udang Metapenaeus yang tertangkap di Teluk Cempi berbeda dengan hasil penelitian di lokasi lainnya. Gerami et al. (2013) mengestimasi bahwa Lm untuk udang kayu di selatan Iran sebesar 27,12 mm, Pillai \& Thirumilu (2013) mengestimasi Lm untuk udang benana di India hanya mencapai 15,4 mm (dikonversi dari panjang total $69 \mathrm{~mm}$ ) dan Saputra et al. (2013) menentukan Lm untuk udang kayu sebesar $51 \mathrm{~mm}$ dan untuk udang benana di perairan Cilacap sebesar 46,5 mm. Perbedaan ini merupakan hal yang umum terjadi karena pertumbuhan maupun ukuran saat matang gonad dipengaruhi oleh ketersediaan makanan yang ada dan kondisi lingkungan dari masingmasing perairan (Effendi, 1997; Suman et al., 2007).

Tingginya persentase udang yang belum matang gonad yang tertangkap nelayan (Gambar 7dan 8) mengindikasikan tingginya tekanan penangkapan pada stok udang yang belum matang gonad dan juga menjadi indikator sedikitnya jumlah udang ukuran dewasa. Beberapa tahun terakhir, terjadi pola lebih banyak udang ukuran kecil dan belum matang gonad yang tertangkap dibandingkan udang yang sudah matang gonad seperti juga halnya di pantai selatan Jawa (Suman et al., 2007), Cilacap (Saputra et al., 2013) dan perairan Sampit (Nurdin \& Kembaren, 2015).

Tekanan penangkapan juga dapat terlihat dari analisa $\mathrm{L}_{\mathrm{c}}$ udang benana dan udang kayu yang lebih kecil dari $\mathrm{L}_{\mathrm{m}}$. Kondisi yang sama juga ditemukan di perairan Cilacap (Saputra et al., 2013). Jika udang yang belum matang gonad terus dieskplotasi tanpa pengelolaan yang tepat, maka kelebihan tangkap pertumbuhan (growth overfishing) dan rekruitmen (recruitment overfishing) akan terjadi. Recruitment overfishing didefinisikan sebagai penangkapan berlebih sebelum ikan matang gonad, sedangkan growth overfishing didefinisikan sebagai penangkapan berlebih sebelum ikan mencapai ukuran optimal (Diekert, 2011). Menurut Baihaqi \& Satria (2016), ukuran hasil tangkapan udang di Teluk Cempi semakin mengecil yang diindikasikan dari makin kecilnya ukuran mata jaring dari pukat tasih udang (bottom gill net dan trammel net) yang digunakan nelayan. Oleh karena itu perlu dilakukan alternatif pengelolaan yang tepat agar populasi udang Teluk Cempi tetap lestari.

\section{KESIMPULAN}

Nisbah kelamin udang kayu dan benana betina lebih besar dibandingkan udang jantan (lebih dari 60\%). Panjang karapas udang benana dan udang kayu betina lebih besar dibandingkan yang jantan. Pola pertumbuhan udang benana dan udang kayu adalah alometrik negatif. Udang benana dan udang kayu di Teluk Cempi dapat memijah sepanjang tahun. Hasil tangkapan udang didominasi udang yang belum matang gonad (TKG I-II). Udang benana pertama kali matang gonad $\left(\mathrm{L}_{\mathrm{m}}\right)$ pada ukuran 24 $\mathrm{mm}$ dan $\mathrm{L}_{\mathrm{m}}$ udang kayu pada ukuran $26,2 \mathrm{~mm}$. Ukuran udang benana pertama kali tertangkap $\left(\mathrm{L}_{\mathrm{c}}\right)$ adalah 16,25 mm (jantan) dan 19,69 mm (betina), sedangkan $\mathrm{L}_{\mathrm{c}}$ udang kayu diperoleh $19 \mathrm{~mm}$ (jantan) dan 24,57 mm (betina). Tekanan penangkapan udang di Teluk Cempi sudah sangat intensif yang terindikasi dari tingginya hasil tangkapan udang yang belum matang gonad dan nilai $\mathrm{L}_{\mathrm{c}}$ yang lebih kecil dari $\mathrm{L}_{\mathrm{m}}$.

\section{PERSANTUNAN}

Tulisan berjudul "Beberapa Aspek Biologi Udang Benana (Metapenaeus dobsoni) dan Udang Kayu (M. affinis) di Perairan Teluk Cempi, Nusa Tenggara Barat" merupakan bagian dari penelitian Pengkajian Kesesuaian Perairan Teluk Cempi, NTB Sebagai Kawasan Konservasi Sumberdaya Udang.Sumber dana penelitian ini adalah APBN pada tahun anggaran 2013. Terima kasih juga penulis ucapkan kepada Drs.Bambang Sumiono, M.Si dan Dra. Sri Turni Hartati, M.Si yang telah mengevaluasi makalah ini.

\section{DAFTAR PUSTAKA}

Achuthankutty, C.T., \& Parulekar, A.H. (1986). Growth of Penaeid Prawns in Goa Waters. Indian Journal of Marine Sciences 15, 117-120.

Badan Perencanaan Pembangunan Daerah \& Badan Pusat Statistik Provinsi NTB. (2014). Nusa Tenggara Barat Dalam Angka Tahun 2014 (p. 627). Provinsi NTB: Badan Perencanaan Pembangunan Daerah \& Badan Pusat Statistik.

Baihaqi, \& Satria, F. (2016). KarakteristikAlat Tangkap dan Hasil Tangkapannya di Teluk Cempi.DalamArio, D., Boer, M. \& Wiadnyana, N.N. (Ed.). Model konservasi ekosistem untuk pemulihan dan keberlanjutan potensi sumber daya ikan Teluk Cempi, Nusa Tenggara Barat (pp. 120-135). Jakarta: Badan Penelitian dan Pengembangan Kelautan dan Perikanan.

Chan, T.Y.(1998). Shrimps and Prawns. Dalam Carpenter, K.E. \& V.H.Niem (eds). FAO species identification guide for fishery purposes. The living marine resources of the Western Central Pacific (p. 851-971). Vol. 2. Cephalopods, crustaceans, holothurians and sharks. Rome: FAO.

da Costa, R.C., Branco, J.O., \& Machado, I.F. (2010). Population biology of shrimp Artemesia longinaris (Crustacea; Decapoda: Penaeidae) from the southern coast of Brazil. Journal of the Marine Biological Association of the United Kingdom 90, 1-7. 
Diekert, F.(2012). Growth Overfishing: The Race to Fish Extendsto the Dimension of Size. Environ Resource Econ. 52, 549-572.

Effendie, M.I. (1997). Biologi Perikanan (p. 163). Yogyakarta: Penerbit Yayasan Pustaka Nusatama.

Gerami, M.H., Ghorbani, R.S., Paighmabari, Y., \& Momeni, M.(2013). Reproductive Season, Maturation Size ( $\left.\mathrm{L}_{\mathrm{m}} 50\right)$ and Sex Ratio of Metapenaeus affinis (Decapoda: Penaeidae) in Hormozgan Shrimp Fishing Grounds, South of Iran. International Journal of Aquatic Biology 1(2), 48-54.

Gillet, R. (2008). Global Study ofShrimp Fisheries (p. 331). Rome: FAO.

Hashemi, S.A., Eskandary, G, \& Sedaghat, S. (2012). LengthWeight and Length-Length Relationships of Metapenaeus affinis (H. Milne-Edwards, 1837) in Northwest of Persian Gulf (Khuzestan Coastal Waters, Iran). American-Eurasian J. Agric. \& Environ. Sci. 12(10), 1339-1342.

Hedianto, D.A.,\& Riswanto. (2014). Karakteristik Biologi Udang Dogol (Metapenaeus affinis, Milne-Edward 1837) di Perairan Kubu Raya, Kalimantan Barat. Prosiding Seminar Nasional Perikanan Indonesia, 83-89.

Kjesbu, O. S. (2009). Applied Fish Reproductive Biology: Contribution of Individual Reproductive Potential to Recruitment and Fisheries Management.DalamJakobsen, T., Fogarty, M. J., Megrey, B. A. \& Moksness, E. (eds.) Fish Reproductive Biology: Implications for Assessment and Management(pp.488). Oxford:Wiley-Blackwell.

King, M.G. (2012). Fisheries Biology, Assessment and Management(p. 382). $2^{\text {nd }}$ edition. Blackwell publishing.

Matthews, GA. (1982). Relative Abundance and Size Distributions of Commercially Important Shrimp During The 1981 Texas Closure. Marine Fisheries Review 449, 5-15.

Naamin, N. (1984). Dinamika Populasi Udang Putih (Penaeus merguiensis de Mann) di Perairan Arafura dan Alternatif Pengelolaannya (pp.277). Disertasi. Fakultas Pascasarjana. Institut Pertanian Bogor.

Nalini, C. (1976). Observation on The Maturity and Spawning of Metapenaeus monoceros (fabricius) at Cochin. Indian Journal of Fisheries 23 (1-2), 23-30.

Nastiti, A.S., M.R.A. Putri., \& H. Saepulloh. (2012). Teluk Cempi Sebagai Kawasan Penghasil Udang yang Potensial di Nusa Tenggara Barat. Prosiding Seminar Nasional Perikanan Tangkap, 325-332.

Nurdin, E., \& Kembaren, D.D. (2015). Parameter Populasi Udang Putih (Penaeus merguiensis) di Perairan Sampit dan Sekitarnya, Kalimantan Tengah. Bawal7 (2), 103-109.
Ogbonna, J.C. (2001). Reducing the impact of tropical shrimp trawling fisheries on the living marine resources through the adoption of environmentally friendly techniques and practices in Nigeria.Dalam Fishery Technology Service. Tropical Shrimp Fisheries And Their Impact On Living Resources. Shrimp fisheries in Asia: Bangladesh, Indonesia and the Philippines; in the Near East: Bahrain and Iran; in Africa: Cameroon, Nigeria and the United Republic of Tanzania; in Latin America: Colombia, Costa Rica, Cuba, Trinidad and Tobago, and Venezuela. Rome:FAO.

Pillai, S.L.,\&Thirumilu,P.(2013). Fishery and stock assessment of Metapenaeus dobsoni (Miers, 1878) off Chennai. Indian Journal of Geo-Marine Sciences42(4), 448-452.

Ramamurthy, S., \& Manickaraja, M. (1978). Relation Between Tail and Total Lengths and Total and Carapace Lengths for Three Commercial Species of Penaeid Prawns of India.Indian Journal of Fisheries 25 (1,2), 233-236.

Saputra, S.W., Sukimin, S., Boer, M., Affandi, R., \& Monintja, D.R. (2005). Aspek Reproduksi dan Daerah Pemijahan Udang Jari (Metapenaeus elegans De Man, 1907) di Laguna Segara Anakan, Cilacap, Jawa Tengah. Ilmu Kelautan 10 (1), 41-49.

Saputra, S.W., Solichin, A., \& Rizkiyana, W. (2013). Keragaman Jenis dan Beberapa Aspek Biologi Udang Metapenaeus di Perairan Cilacap, Jawa Tengah. Journal of Management Of Aquatic Resources,2(3), 37-46.

Suman, A., Prisantoso,B.I.,\&Bintoro, G. (2007). Population Dynamics of Endeavour Shrimp (Metapenaeus elegans) in the Waters of South Coast of Java. Ind. Fish Res. J. 13(1), 4954.

Suman,A.(2010). Sumber Daya Udang Penaeid di Indonesia dan Alternatif Pengelolaannya Secara Berkelanjutan. Orasi Pengukuhan Profesor Riset(p.52). Badan Penelitian dan Pengembangan Kelautan dan Perikanan. Kementerian Kelautan dan Perikanan. Jakarta.

Sumiono, B., \& Prisantoso,B. I. (1989). Potensi dan Tingkat Pengusahaan Sumberdaya Udang Penaeid di Perairan Teluk Cempi Nusa Tenggara Barat. Jurnal Penelitian Perikanan Laut57, 109-118.

Triharyuni, S., Sulaiman, P.S.,\& Rianto, J. (2012). Hubungan Panjang Berat, Tingkat Eksploitasi dan Fluktuasi Hasil Tangkapan Albakora (Thunnus alalunga, Bonnaterre) di Samudera Hindia. J. Lit. Perikan. Ind. 18(1), 35-41.

Udupa, K.S. (1986). Statistical Method of Estimating the Size at First Maturity in Fishes. Fishbyte. 4 (2), 8-10. ICLARM. Metro Manila. 
Lampiran 1. Hubungan antara panjang total (X) dan panjang karapas udang (Y) (Ramamurthy \& Manickaraja, 1978) Apendix 1. Correlation of total length $(X)$ and carapace length shrimp (Y) (Ramamurthy \& Manickaraja, 1978)

\begin{tabular}{cl}
\hline \multicolumn{1}{c}{ Jenis udang/Shrimp } & \multicolumn{1}{c}{ Persamaan /Equation } \\
\hline Metapenaeus dobsoni & $\mathrm{Y}=-5.431+0.302 \mathrm{X}$ \\
Betina & $\mathrm{Y}=-0.758+0.24 \mathrm{X}$ \\
Jantan & $\mathrm{Y}=-4.6+0.29 \mathrm{X}$ \\
Gabungan & \\
Metapenaeus affinis & $\mathrm{Y}=-5.604+0.301 \mathrm{X}$ \\
Betina & $\mathrm{Y}=-1.569+0.254 \mathrm{X}$ \\
Jantan & $\mathrm{Y}=-6.102+0.303 \mathrm{X}$ \\
Gabungan &
\end{tabular}

